\title{
Linguistic Challenges in Solving Mathematics Word Problems: A Case of EFL University Students
}

\author{
Namirah Fatmanissa ${ }^{1,2 *}$ Maria N. R. Novianti ${ }^{3}$ \\ ${ }^{1}$ Mathematics Education Department Sampoerna University \\ ${ }^{2}$ Universitas Negeri Surabaya \\ ${ }^{3}$ English Language Education Department, Sampoerna University \\ *Corresponding author. Email: namirah.f@sampoernauniversity.ac.id
}

\begin{abstract}
One of the biggest challenges English as Foreign Language (EFL) learners face in solving Mathematics word problems at the English college level is understanding the information presented through that language. This study aimed to investigate the importance of language in Mathematics word problems tests by analyzing students' performance on linguistically modified mathematics word problems. Forty-four university students were given ten Postsecondary Education Readiness Test (PERT) Mathematics word problems, along with parallel items that were modified based on a framework of Language Factor in Mathematics Tests to reduce their linguistic complexity. Students' written works were compiled and graded. Interviews were conducted to further investigate students' linguistic challenges in solving the problems. The findings revealed that EFL students with low English ability benefited more from the modification by showing greater score gain. First, third, and fourth-year students benefited more from the modification than second year and fast track students, while there was no difference observed based on gender. Some examples of students' work in overcoming challenges due to long nominals, relative clauses, and complex question phrases were described to further explain the case. The study concluded that linguistic modification is necessary, and lecturers' awareness of linguistic challenges should be promoted.
\end{abstract}

Keywords: Mathematics, Word problems, EFL, Linguistic challenges.

\section{INTRODUCTION}

Word problems have unique characteristics that make them different from other types of problems. Word problem is a problem that is situated in a real-life context [1]. By being put into a context, a word problem is written in sentences rather than in a mere mathematical symbol. A word problem is constructed from three components, i.e., set-up component, information, and question [2]. These components construct a word problem and understanding them is an essential process if a student wants to solve it. However, because word problems consist of both language and mathematical aspects, solving them is challenging, either when given in students' mother language or foreign language [3].

Some research examining the students' performances on the word problem has been carried out in Indonesia. The focus of the research is also varied related to analysis on students' difficulties [4,5]; investigations on the effectiveness of certain strategies to cope with the students' difficulties [6-8]; or analysis on the learning environment towards the implemented word problems $[9,10]$. However, research on the language difficulties or challenges related to Mathematic word problems is still few in Indonesia [11,12].

The internationalization process in Indonesia's higher education has been increasing [13], and one of them is the increasing number of international classes using English as the medium of instruction, and Mathematics content is a part of the instruction itself. The use of English in academic education has started from the first semester in which several students have no or few experiences using English in their learning environment previously. These students are categorized as those who use English as a Foreign Language or are commonly considered as EFL learners.

As EFL learners, the challenges are more complex to solve the word problems. Some studies found that those with less contextual understanding will have more difficulties solving the world problems despite their average ability to solve the Mathematic word problems in 
their native language [14-16]. In other words, the mastery of the native language is the essential skill or knowledge to understand the foreign language and possibly help the students find the meaning by correlating or comparing the structure of both languages [17]. The native language (Indonesian) comprehension itself is influenced by the complexity in sentences, the part of speech in vocabularies, and the concrete representation in the questions given [18]. Those aspects could be the considerations to modify the English language word problem similar to the structure in the native language resulting in the better process of language understanding.

This study aims to investigate the gap in the students' performance when word problems are given in different language complexity. In addition, the investigation will analyze the language challenges faced by the students solving the Mathematic world problem. The result of this study could contribute to other students from different institutions who have similar cases to use English as a medium of instruction.

\section{THEORETICAL FRAMEWORK}

\subsection{English as Foreign Language (EFL) in Mathematics classroom}

The use of English in Mathematics classroom which contains non-English-native students, either who consider English as a second language (English as Second Language, ESL) or a foreign language (English as Foreign Language, EFL) has been investigated by several studies. The studies were dominantly conducted in English-speaking countries with various language backgrounds of their students. For example, a study in Australia [19] identified difficulties faced by university students whose first language was non- English. This study stated that students with English difficulties found it challenging to learn applied mathematics and differential equation courses due to massive written and verbal descriptions embedded in them, which demanded strong comprehension skills. This even was applied to students with strong mathematical abilities. This study recommended supports provided by the institution to help the challenged students. Another study in Hong Kong [14] specifically investigated linguistic challenges from a language perspective. This study recommended the importance of teachers and lecturers paying attention to words and sentence structures before giving them to EFL learners. This study recommended the collaboration between Mathematics and English educators to help students face the challenges.

In Indonesia, issues of using English in mathematics classrooms emerged along with the selection of several schools as International Standard School (Sekolah Bertaraf Internasional, SBI) in 2006 by the Ministry of National Education. This issue also emerged in higher education along with the policy to internationalize universities to promote global competitiveness [13]. The internationalization of higher education institutions was hoped to elevate students' competitiveness by utilizing English as the language of instruction, including in Mathematics. The practices of using English as a Foreign Language (EFL) in learning attracted many to conduct related research.

Studies about EFL students in Indonesia were dominated by investigations of students' difficulties like what [20-23] did, or teachers' such as a study by [24-26] in middle schools. These studies highlighted the linguistic difficulties in understanding words or academic terms in both learning and solving problems. In other streams of studies by $[26,27]$ aimed to examine strategies or practices to help face the challenges. Such practices involved the use of media or translating books and classroom instruction.

\subsection{Mathematics word problems and linguistic difficulties}

Mathematics word problems are problems that use daily phenomena as the task context [28]. In solving them, at least three steps are required i.e., understanding the information, translating it to a mathematical model and solving the model, and interpreting the solution back to its real-life context. The process of solving word problems expects students to use their language understanding of the written text and combine it with the mathematical understanding they have [19].

Several studies had been done related to linguistic challenges students faced while solving word problems. The challenge lied in students' ability in using the mathematics register, a collection of meaning appropriate to its function in mathematics. Mathematics register is the language characteristics possessed by word problems that make students feel like being faced with a new language [29]. Being EFL learners, students are not only expected to understand English as the written language of the problem, but they are also expected to work within it and within the mathematics register, while on the other hand sometimes even they do not understand daily English. [30].

\subsection{Linguistic modification of word problems}

To better understand the challenges encountered by students while solving word problems, aspects that contribute to the language complexity of them need to be recognized. Abedi and Lord [18] explained those aspects as given in Table 1. Students' linguistic challenges emerged from the complexity of each aspect. For example, an active phrase was preferred from a passive phrase. "A marble is taken from a bag" using a passive voice was considered more difficult to understand than "if you take a marble from a bag" which used active voice. 
The linguistic modification framework proposed by Abedi, and Lord is used to lessen linguistic challenges contained in a word problem. Each modification aspect allows for a specific analysis of the language challenge.

Table 1. Linguistic modification framework

\begin{tabular}{|c|l|l|}
\hline No & \multicolumn{1}{|c|}{ Aspect } & \multicolumn{1}{c|}{ Modification } \\
\hline 1 & $\begin{array}{l}\text { Familiarity or } \\
\text { frequency of } \\
\text { non-math } \\
\text { vocabulary }\end{array}$ & $\begin{array}{l}\text { unfamiliar or infrequent } \\
\text { wordswere changed }\end{array}$ \\
\hline 2 & Voice of verb phrase & $\begin{array}{l}\text { passive verb forms were } \\
\text { changed } \\
\text { to active }\end{array}$ \\
\hline 3 & Length of nominals & $\begin{array}{l}\text { long nominals were } \\
\text { shortened }\end{array}$ \\
\hline 4 & Conditional clauses & $\begin{array}{l}\text { conditionals were replaced } \\
\text { with separate sentences, or } \\
\text { the order of conditional and } \\
\text { main clause was } \\
\text { changed }\end{array}$ \\
\hline 5 & Relative clauses & removed or recast \\
\hline 6 & Question phrases & $\begin{array}{l}\text { complex question phrases } \\
\text { were } \\
\text { changed to simple question } \\
\text { words }\end{array}$ \\
\hline 7 & $\begin{array}{l}\text { Abstract or } \\
\text { impersonal } \\
\text { presentations }\end{array}$ & \begin{tabular}{l} 
made more concrete \\
\hline
\end{tabular}
\end{tabular}

\section{METHODS}

This study employed both quantitative and qualitative analysis. The descriptive quantitative analysis was done to participants' scores in both versions of the test; while the qualitative analysis was done to further explain the linguistic challenges faced by participants while solving word problems.

Table 2. General participants' information

\begin{tabular}{|c|c|c|c|c|c|}
\hline \multirow{2}{*}{ Cohort } & \multicolumn{2}{|c|}{ Gender } & \multicolumn{3}{c|}{ English Ability } \\
\cline { 2 - 6 } & Female & Male & High & Fair & Low \\
\hline 2020 & 14 & 12 & 5 & 15 & 6 \\
\hline 2019 & 9 & 5 & & 10 & 4 \\
\hline 2018 & 3 & & & 3 & \\
\hline 2017 & 1 & & & & 1 \\
\hline
\end{tabular}

The participants of the study were 44 students in one of the universities in Jakarta, Indonesia (as shown in Table 2). The test instrument was constructed by modifying ten-word problems in Postsecondary Education Readiness Test (PERT) Mathematics on several topics such as arithmetic operations, fractions, linear equations, inequalities, and quadratic equations. There are two versions of items in the test: original item and modified item. A pair of items had the same mathematical expectation, but the modified item had less language complexity. The pair's similar mathematical expectation was tested by an external validator of mathematics education while the language complexity was tested by an English language expert. The original item was named by $1 \mathrm{a}, 2 \mathrm{a}$, and so on, while its parallel modified item was named by $1 \mathrm{~b}, 2 \mathrm{~b}$, and so on.

Linguistic modification of the original items referred to the framework by Abedi and Lord [18]. Each participant was tested twice to avoid testing an original item together with its paper was collected right after the test. Students' answers were graded for the original and modified version of the test.

Besides taking the test, the participants were interviewed to further explore their thoughts while solving the problems. The students were shown two versions of the parallel items, i.e., version $\mathrm{A}$ for the original and $\mathrm{B}$ for the modified. The interview questions were, but were not limited to, as follows: (1) If you did not have much time left in a test, which version of the item would you choose? Why? (2) Was there any word you found difficult from the test? Why do you think so?

The interview transcripts and students' work were coded based on the linguistic challenge found (i.e., FFFamiliarity or frequency, V- Voice, L- Length of nominals, CC-Conditional clauses, RC- Relative clauses, QP- Question phrases, AIP- Abstract or impersonal presentations).

\section{FINDINGS}

Students showed different performances between the modified and the original questions. The mean and score gain was displayed in Table 3 . There are $60 \%$ of students who obtained better scores in the modified versions of the test than the original ones. Score gains were observed in student's cohort 2017, 2018, and 2020, and the students with low English ability.

The mean score of students of cohort 2019 showed an interesting fact. These students did not benefit from the linguistic modification, shown by the lower mean score in the modified version. One of the things that may explain this is that $76 \%$ of them have high and fair English ability, which could be said that they had no problems in dealing with English text. This was in line with the findings from the English ability category that revealed students with high ability had lower performance in the modified version of the test. Female students showed a lower mean score in the modified version while male students showed no difference. It can be said that the modification did not favor one gender over another.

Students who benefited from the modification showed different work between the original version of the items and the modified ones. Despite working on the questions with equal mathematical expectation, these students performed better in the modified version of the item, and the challenge shown in the original item parallel to it was not found later. Students' challenges in solving word 
problems that were found to be overcome included the challenges due to the existence of relative clauses, long nominals, and complex question phrases.

Table 3. Mean and score gain of the test

\begin{tabular}{|c|c|c|c|}
\hline \multirow{2}{*}{$\begin{array}{l}\text { Participant } \\
\text { category }\end{array}$} & \multicolumn{3}{|c|}{ Mean score } \\
\hline & Original & Modified & Gain \\
\hline \multicolumn{4}{|l|}{ Cohort } \\
\hline 2017 & 8,00 & 10,00 & 2,00 \\
\hline 2018 & 8,33 & 8,67 & 0,34 \\
\hline 2019 & 8,89 & 8,22 & $-0,67$ \\
\hline 2019 (Fast track) & 9,80 & 9,20 & $-0,60$ \\
\hline 2020 & 8,69 & 8,81 & 0,12 \\
\hline \multicolumn{4}{|l|}{ Gender } \\
\hline Female & 8,78 & 8,67 & $-0,11$ \\
\hline Male & 8,88 & 8,88 & 0,00 \\
\hline \multicolumn{4}{|l|}{ English Ability } \\
\hline High & 8,79 & 8,67 & $-0,12$ \\
\hline Low & 8,91 & 9,00 & 0,09 \\
\hline
\end{tabular}

\subsection{Relative clauses}

In the original version of a question that was modified by recasting the relative clause, students showed difficulties in noticing all information needed to work on the question. By removing or recasting the relative clause, the information in the item was spread rather than converged in one sentence, allowing students to notice the information easier. For example, in question no. 1, student KA missed the information that the gas needed was for a two-ways trip (Fig. 2). In item no. 1, the relative clause was re-casted by reducing the word 'to' and separated the information of "see your friends and return home" and the question into two different sentences. In the modified item, KA succeeded to multiply the volume of gas by two, resulted a correct answer.

The reason was confirmed by students through the following excerpt of the interview:

"For me, this is my opinion ya miss, even though this version (original) is shorter, I prefer this version B (modified) because it has clearer instruction, although seemingly longer than version A (original). ... I recheck my works and I didn't notice that I have to calculate, emm, the apa itu bolak-baliknya (two-ways trip)"

KA stated that despite being longer, the modified version was easier to understand since the information was broken apart into two sentences. She realized the fact that she did not notice the need to calculate for a two-ways trip in the original version.
(No. 1 original)Your car gets about 20 milesper gallon. You are planning to drive to see your friends who live about 850 miles away. How mary gallons of gas willyou need to purchase to make the trip to seeyour friends and to return home?

$$
\frac{850}{20}=42.5
$$

(No. 1 modified) Your car gets about 20 milesper gallon. You are planning to drive to seeyour fri ends who live about 850 miles away. Youwant to seeyour friends and then return home. Howmany gallons of gas willyou need to purchase?

Figure 1 KA's work on item no. 1.

\subsection{Long Nominals}

(No. 2 original) A rod of wood has length of $70 \mathrm{~cm}$, and it is cut by 8 inches. What is the length of wood rod after it is cut? $(1$ inch $=2.54 \mathrm{~cm})$.

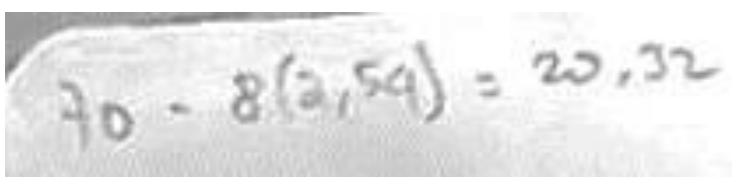

No. 2 modified) A rod of wood is $70 \mathrm{~cm}$ long. Then, Anne cuts it by 8 inches. What is the length of wood rod now? ( 1 inch = $2.54 \mathrm{~cm})$.

$$
\begin{aligned}
& 8 \times 2,54 \mathrm{~cm}=20,32 \\
& 70-20,32=49,68
\end{aligned}
$$

Figure 2 SA's work on item no. 2 with long nominals.

As shown in figure 2 above, the original version of a question that was modified by shortening the length nominal, students showed challenges in understanding the information contained in that nominals for instance in the work of a student, SA, for no. 2. The original version of the item contained a long nominal "the length of wood rod after it is cut" which at the same time was the objective of the item question. In the original version, the student failed to recognize that the length of wood being asked was that after being cut. Which resulted in her answer of only converting 8 inches to centimetres. SA managed to get the point being asked when doing the modified version. She subtracted the converted length from the original length which was $70 \mathrm{~cm}$.

Another student, AA, had a similar difficulty due to long nominal in no. 5 (Fig. 3). The original version of the item contained a long nominal "the largest number among those three-consecutive numbers" which was also being asked by this item. His work on both versions of the item was not so different in terms of how he modelled the question into an equation and got the value of $x$. 
However, in the original version, he failed to identify that the one being asked was the largest number and answered the unknown variable instead. In the modified version, this nominal was replaced by a pronoun, allowing a focus to the main information being asked i.e. "largest number". In this version of the item, he managed to correctly grasp the main question and correctly answer by adding 2 to the value of $x$.

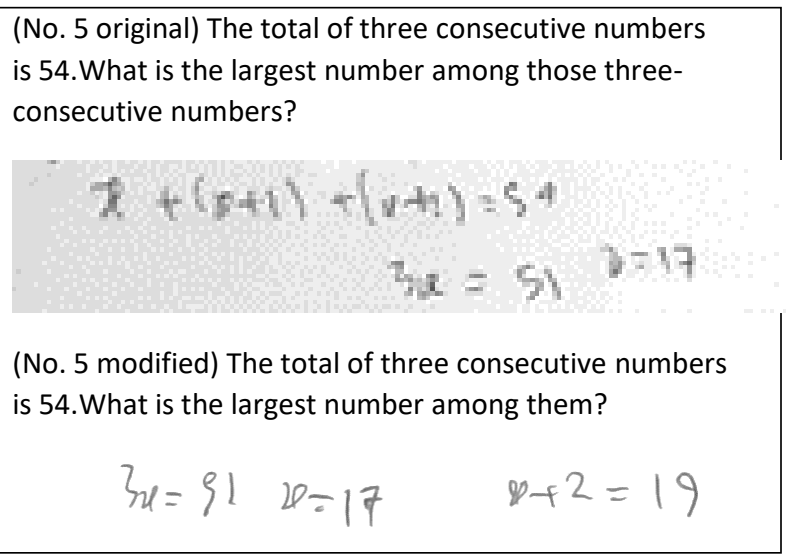

Figure 3 AA's work on item no. 5 with long nominal.

The interview revealed another fact about his work as stated in the following excerpt:

"For me who is struggling in gaining focus, I think version $\mathrm{A}$ is clearer because it shows exactly what is "them". In version B, the meaning of "them" should be found in previous sentences, so when we are in a hurry the focus can't be there just in time. ... the keywords "the largest" I might didn't focus $y a "$

AA stated his preference towards the original version, but once being asked related to his work, he realized that he might not focus on the keyword 'the largest' in the question. This explained the sentence structure may shadow the keyword and thus made him fail in noticing the point of interest

\subsection{Complex question phrase}

In the original version of a question that was modified by simplifying the question phrase or sentence, students were challenged in understanding the objective of the question or incorporating all information needed when it was included in the question phrase or sentence. For instance, in question no. 4 (Fig. 4), the question sentence was simplified by putting one of the required objectives, i.e., the ratio of the two lakes, in the options. By doing this, the question sentence in the item was shortened and allowed students to focus on the largest lake as the point of interest.

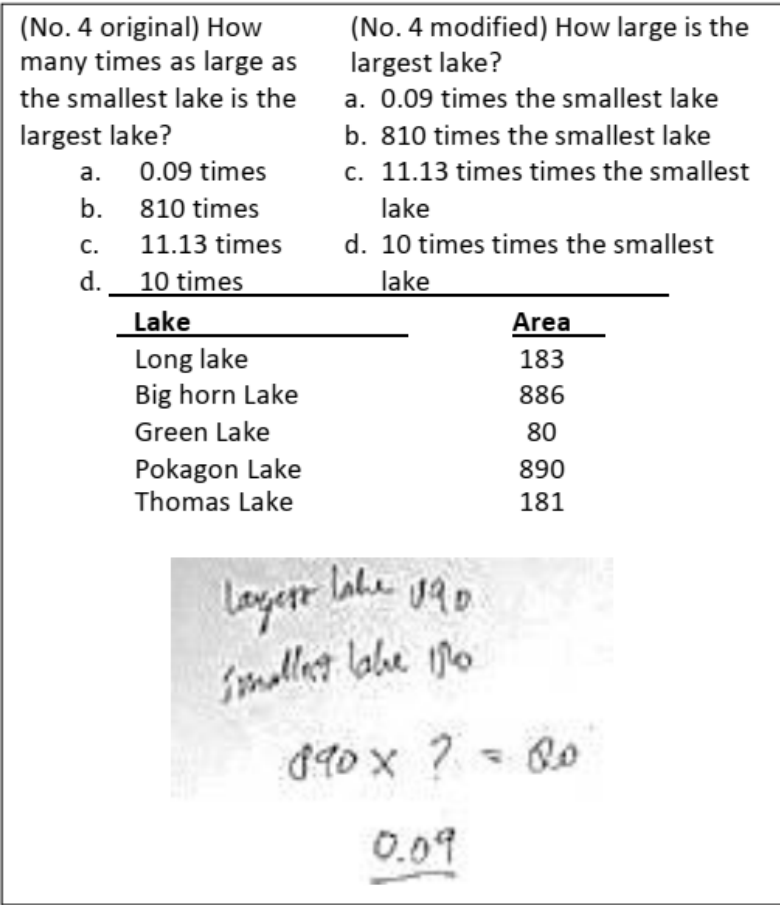

Figure 4 Work of AF in no. 4 with complex question sentences.

Challenges in this item came from determining the largest lake as the point of interest, i.e. how large it is with respect to the smallest lake. In this case, students must find the ratio of the largest lake with the smallest lake, not the other way around. In figure 4 , AF found it difficult to come up with the correct ratio. They got confused with the complex sentence "How many times as large as the smallest lake is the largest lake" and deliberately calculated $80 / 890$ as the ratio. The modified version brought this student easily noticed that the ratio intended was 80/890 as the options obviously were phrased into "... times the smallest lake".

This corresponded to AF's opinion while being asked about the two versions of the item:

"I think I prefer version B because of the structure of the version is easier to read compared to version A. Because aku sempet bingung kalo baca yang version A miss (I got confused while reading version A, miss). Mungkin dua tiga kali baru paham (Maybe two- or three-times reading will make me understand). Kalo version B kan straight to the point. How large is the largest lake".

The modified version allowed AF to directly focus on the point of interest i.e., the size of the largest lake. He stated that the original version confused him and made him lose focus on what was being asked.

\subsection{Students with good English}

Some students with good English showed no difficulties in understanding both the original and modified version. This was shown by either correct 
answers in both versions of the test or being careless despite understanding the item fully. The latter was shown by the work of RA for no. 5 (Fig 5). In her work, she did understand that the largest number among the three numbers was asked. However, due to her error in dividing 54 by 3 , she got a wrong answer.

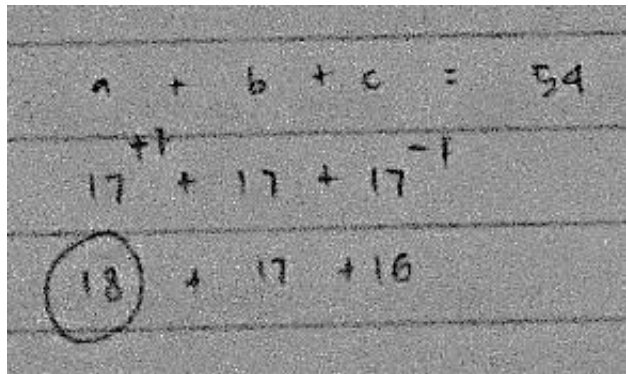

Figure 5 RA's work on no. 5.

Students with good English ability showed no difficulties in understanding both the original and modified version, despite preferring one version to another. For example, in the excerpt of student namely SP about both versions of no. 9, she said:

"I think the 'if' emphasizes the question. ... I personally choose a question that gives question early...It is quite similar, I think. Mmm..because it is about comparison, we have to focus on reading the question. ... I think we should put more attention to a question like this. I don't say that this is difficult, but it just needs more focus in order to understand this question."

SP conveyed her confidence in understanding the question by saying that it was not difficult to understand the question, but it just needed more attention. She also said that the two versions did not make them work differently for the mathematics, explaining her correct answers for both versions of the item.

\section{DISCUSSIONS AND CONCLUSIONS}

The modification of the word problems gave advantages to EFL students especially the ones with low English ability. By modifying the sentences in the word problems, students managed to overcome their linguistic challenges and noticed the important information presented in the item. For students with good English ability, the modification seems not to benefit them, shown by decreasing scores or similar work presented in both versions of the test. Some studies revealed similar findings. For example, a study by Haryanto [20], found that students with low English felt afraid of doing a task in English, while students with good English ability showed steady motivation and claimed no difficulties being felt. How modification did not benefit students with high English ability was also revealed by the study of Abedi et al. [31]. In this study, students with low English ability had greater score gain than students with high English ability.
By understanding that most students benefited from the linguistically modified items, the linguistic modification in English-written mathematical tests is a necessary effort. The effort was necessary to minimize the effects put by language complexity on students' performance in solving word problems, regardless of how skillful the students are [32]. The modification brings several lessons on assessing students on solving math word problems. First, the modification did benefit students who struggled with understanding the test given in English despite having a good mathematical skill needed to solve it. In other words, the modification allowed the lecturer to be more objective in assessing students' mathematics by minimizing the language factor. Second, the language aspects of a test did affect students' performance and thus, the lecturer's active involvement in addressing the issue should be promoted. Whether the language brings challenges due to long nominals, complex phrases, or other linguistic aspects should be put as a concern by the lecturer. Thus, the way language was used and incorporated into mathematics activity, including tests, should be given more attention [30].

Finally, the study revealed how students perceived similar mathematics problems differently based on how they were constructed. Students' understanding of the mathematics problem given was affected by the complexity of the questions. Providing helps to students to be aware of this language issue is also necessary as it contributes to their mathematics performance [33].

This study does not claim that linguistic modification will benefit all types of students on all mathematics topics, as also revealed by findings for students with high English ability. This study is limited by its participants selection and mathematics test numbers and coverage. However, this study has tried to address the issue of how EFL learners perceived mathematics word problems from the language perspective. In the future, more specific studies addressing linguistic issues in a mathematical context are necessary. Such studies may investigate students' level of mathematics problem understanding or whether one linguistic aspect brings more challenges than another (e.g., complex phrases compared to long nominals).

\section{AUTHORS' CONTRIBUTIONS}

All authors conceived and designed this study. All authors contributed to the process of revising the manuscript, and in the end, all authors have approved the final version of this manuscript.

\section{ACKNOWLEDGMENTS}

This research was supported by the Indonesia Ministry of Research and Technology under the Beginning Lecturer Research Grant. We would like to thank both mathematics education and English language experts for 
their feedback on the construction of instrument items. We also thank students for their participation and cooperation in this study.

\section{REFERENCES}

[1] L. Verschaffel, W. van Dooren, B. Greer, S. Mukhopadhyay, reconceptualising word problems as exercises in mathematical modelling, J. fur Math., 31(1) (2010) 9-29. DOI: https://doi.org/10.1007/s13138-010-0007-X.

[2] S. G. Gerofsky, The Word Problem As Genre in Mathematics Education, Word J. Int. Linguist. Assoc.,no. November, 1999.

[3] N. Fatmanissa and Kusnandi, The Linguistic Challenges of Mathematics Word Problems: A Research and Literature Review, Malaysian J. Learn. Instr., vol. Special Is, pp. 73-92, 2017.

[4] N. Nurkaeti, Polya'S Strategy: an Analysis of Mathematical Problem Solving Difficulty in 5Th Grade Elementary School, EduHumaniora | J. Pendidik. Dasar Kampus Cibiru 10(2) (2018) 140, DOI: https://doi.org/10.17509/eh.v10i2.10868.

[5] A. Jupri, P. Drijvers, Student difficulties in mathematizing word problems in Algebra, Eurasia J. Math. Sci. Technol. Educ. 12(9) (2016)2 4812502.

DOI: https://doi.org/10.12973/eurasia.2016.1299a.

[6] N. Istiqomah, J. Poerwanti, Hadiyah, Penerapan Strategi Pembelajaran Think-Talk-Write (TTW) Untuk Meningkatkan Keterampilan Menyelesaikan Soal Cerita Pecahan, Didakt. Djiwa Indria, 3(8) (2013) 1-8.

[7] F. Angraeni, Penerapan Metode Polya Untuk Meningkatkan Hasil Belajar Siswa Kelas X TSM SMK Negeri 1 Parigi Dalam Menyelesaikan Masalah Soal Cerita Sistem Persamaan, J. Kreat. Tadulako Online 2(4) (2015) 288-306. URL: http://jurnal.untad.ac.id/jurnal/index.php/JKTO/arti cle/view/4121.

[8] Junaidah, M. Shaifuddin, Sadiman, S. Kamsiyati, Penerapan Model Pembelajaran Problem Posing Tipe Pre- Solution Posing Untuk Meningkatkan Keterampilan Menyelesaikan Soal Cerita Tentang Bangun Datar Dan Bangun Ruang, J. FKIP UNS 5(3) (2015) 106-110.

[9] A. Wijaya, M. van den Heuvel-Panhuizen, M Doorman, Opportunity-to-learn context-based tasks provided by mathematics textbooks, Educ. Stud. Math., 89(1) (2015) 41-65. DOI: https://doi.org/10.1007/s10649-015-9595-1.

[10] Sumarwati, E. Subroto, S. Pujosudarmo, J. Nurkamto, The Types of Word Problem Discourse Structure in Mathematics Textbook Presented In Indonesian For Primary School Students, J. Educ.
Pract., 5(12) (2014)151-163.

[11] N. Fatmanissa, Kusnandi, D. Usdiyana, Student difficulties in word problems of derivatives: A multisemiotic perspective, Journal of Physics: Conference Series, 1157(3) (2019). DOI: https://doi.org/10.1088/1742-6596/1157/3/032111.

[12] N. Fatmanissa, "Word Problems Of Conic Sections: Analysis Of Linguistic Difficulties," 2018.

[13] S. Soejatminah, Internationalization of Indonesian Higher Education: A Study from the Periphery, Asian Soc. Sci., 5(9) (2009) 70-78. DOI: https://doi.org/10.5539/ass.v5n9p70.

[14] S. Chan, Linguistic challenges in the mathematical register for EFL learners: linguistic and multimodal strategies to help learners tackle mathematics word problems, Int. J. Biling. Educ. Biling, 8(3) (2015) 306-318.

DOI: https://doi.org/10.1080/13670050.2014.988114.

[15] L. S. Fuchs, D. Fuchs, D. L. Compton, C. L. Hamlett, A. Y. Wang, Is Word-Problem Solving a Form of Text Comprehension?, Sci. Stud. Read 19(3) (2015) 204-223.

DOI: https://doi.org/10.1080/10888438.2015.1005745.

[16] G. J. Cuevas, Mathematics Learning in English as a Second Language, J. Res. Math. Educ. 15(2) (1984) 134-144. URL:http://www.jstor.com/stable/748889.

[17] Y. Romero, M. P. Manjarres, How Does the First Language Have an Influence on Language Learning? A Case study in an English ESL Classroom, English Lang. Teach 10(7) (2017) 123-139. DOI: https://doi.org/10.5539/elt.v10n7p123.

[18] J. Abedi, C. Lord, The language factor in mathematics tests, Appl. Meas. Educ. 14(3) (2001) 219-234.

DOI: https://doi.org/10.1207/S15324818AME1403_2.

[19] D. G. Mallet, Walking a mile in their shoes: Nonnative English speakers' difficulties in English language Mathematics classrooms, J. Learn. Des 4(3) (2011) 28-34. DOI: https://doi.org/ 10.5204/jld.v4i3.78.

[20] E. Haryanto, Listening to students voice: A survey of implementation of English as medium of instruction in an international standard school in Indonesia 3 (15) (2012) 111-119.

[21] M. N. Willyarto, D. Werhoru, A. A. Gea, "The use of english in learning mathematics for grade 7 junior high school," Proc. - 2017 Int. Symp. Educ. Technol. ISET 2017, no. April, pp. 177-179, 2017, doi: 10.1109/ISET.2017.48.

[22] Z. D. Ariyani, B. Sumintono, S. N. Azkiyah, "The Investigation of Challenges in Teaching and Learning Mathematics through English at Secondary Schools in," in 2nd International Seminar on Quality and Affordable Education (ISQAE 2013) The, 2013, pp. 277-283. 
[23] E. Saragih, the Practice of Bilingual Instruction of Math and Natural Sciences At International Standard Schools in Indonesia, 20 (2014) 286-296. URL:

https://www.researchgate.net/publication/32014954 6.

[24] E. Hartati, The Language Functions Used By Teachers Of Content Subjects Using English As The Medium Of Instruction (The Case of Mathematics and Science Teachers in Semesta Bilingual Senior High School), English Educ. J. 3(2) (2013) 85-93.

[25] M. K. Dewi, B. Usman, A. Muslem, Use of English in Teaching Mathematics, English Educ. J., 9(1) (2018) 37-56.

[26] K. T. Sipayung, The Impact of Translation Method and Shift on Translation Quality at Bilingual Textbooks of Physics, Mathematics and History, Ling. Cult. 14(1) (2020) 79-85, 2020. DOI: https://doi.org/10.21512/lc.v14i1.6387.

[27] N. R. Wahyuddin, B. Jabu, K. Salija, The Bilingual Instruction In Mathematics International Class ProgramAt State University Of Makassar, 2020.

[28] H. B. Khoshaim, Mathematics teaching using word- problems: Is it a phobia!, Int. J. Instr. 13(1) 855-868, 2020.

DOI: https://doi.org/10.29333/iji.2020.13155a.

[29] M. J. Schleppegrell, The linguistic challenges of mathematics teaching and learning: A research review, Read. Writ. Q. 23(2) (2007) 139-159. DOI: https://doi.org/10.1080/10573560601158461.

[30] L. Jourdain, S. V. Sharma, Language challenges in mathematics education for English language learners: A literature review, Waikato J. Educ. 21(2) (2016) 43-56. DOI: https://doi.org/10.15663/wje.v21i2.269.

[31] J. Abedi, C. Lord, J. Plummer, Final Report of Language background as a variable in NAEP mathematics performance, Natl. Cent. Res. Eval. Stand. Student Test. 1522(310) (1997) 238. URL: http://www.cse.ucla.edu/products/reports/R608.pdf.

[32] L. M. Saija, R. B. Sihotang, Analysis on the Use of English in Economic Mathematics Teaching and Learning (Experimental Study in Universitas Advent Indonesia), J. Padegogik Mat. 1(1) (2018) 32-41. DOI: https://doi.org/10.35974/jpd.v1i1.638.

[33] D. Leiss, J. Plath, K. Schwippert, Language and Mathematics - Key Factors influencing the Comprehension Process in reality-based Tasks, Math. Think. Learn. 21(2) (2019) 131-153. DOI: https://doi.org/10.1080/10986065.2019.15708 